\title{
Selection of pepper parent from a collection of Capsicum annuum landraces based on genetic diversity
}

\author{
Karima Lahbib*, Fethi Bnejdi and Mohamed El Gazzah \\ Biodiversity, Biotechnology and Climate change Laboratory, Department of Biology, Faculty of Sciences El Manar \\ University, 2092 Tunis- Tunisia. \\ Accepted 3 December 2012
}

\begin{abstract}
Phenotypic divergence among eleven landraces belonging to a collection of Capsicum annuum species and maintained at the Faculty of Science, University of Tunis, was quantified by multivariate analysis for seven morphological traits. The multivariate data set was analyzed by canonical discriminant analysis in combination with a clustering procedure using generalized Malahanobis distance D2. The first two canonical variates were significant and accounted for $84.524 \%$ of the total variability. Using generalized Mahalanobis distances, all the 11 landraces were grouped into three clusters. The genetic stocks within cluster had smaller D2 values among themselves than those belonging to different clusters. Accessions FTC-6 and FTC-11 (clusters II and III, respectively) had distinct identity. Multivariate analysis performed indicates large magnitude of phenotypic divergence in the landraces studied and was successful in differentiating the accessions into similar groups on the basis of the measured traits. The characteristics that played the greatest role in differentiation were number of fruits per plant, fruit diameter, placenta weight and fruit length. Plant breeders can use the information on variation among $C$. annuum landraces for pepper improvement yield and for obtaining good segregants in pepper breeding programs.
\end{abstract}

Key words: Capsicum annuum, morphological traits, canonical discriminant analysis, Malahanobis, yield improvement, breeding programs.

\section{INTRODUCTION}

Capsicum annuum $\mathrm{L}$. is a dicotyledonous flowering plant commonly grown worldwide. In temperate areas, C. annuum is an annual herbaceous plant of the Solanaceae family including hot pepper and sweet or bell pepper. The great phenotypic diversity in plant habit and especially in shapes, sizes (Andrews 1995, 1998, 1999; DeWitt and Bosland, 1996) and the horticultural, agricultural and biological diversity have helped to make C. annuum globally important for culinary use (for example, cooked vegetable, food ingredient, colorant),cosmetics (Andrews, 1995, 1999; Bosland, 1994; Bosland and Votava, 2000), medicinally and medically uses (Krishna De, 2003; Cordell and Araujo, 1993; Palevitch and Craker, 1995; Cichewicz and Thorpe, 1996). In Tunisia, pepper germplasm is mainly represented by $C$. annuum species with a number of hot pepper landraces cultivated throughout the country accumulating of a wide range of variation. Pepper ( $C$. 
Table 1. Provenances of the accessions included in this study.

\begin{tabular}{|c|c|c|c|c|}
\hline Accession code & Accessions names & Location source & Latitude & Longitude \\
\hline FTC-1 & Corne de Gazelle & & N37'10'10" & E10 क'28" \\
\hline FTC-2 & Beldi & El Alla, BIzerte & N3/. & E 10228 \\
\hline FTC-3 & Fort de korba & Korba, CapBon & N36 $59^{\prime} 78^{\prime \prime}$ & $\mathrm{E} 10^{\circ} 36^{\prime} 27^{\prime \prime}$ \\
\hline FTC-4 & Fort de korba & Menzel Temim, CapBon & N36 ${ }^{\circ} 78^{\prime} 46^{\prime \prime}$ & E10 98'33" \\
\hline FTC-5 & Knaiss & Msaken, Sousse & N35 '68'37”' & $\mathrm{E} 10^{\circ} 51^{\prime} 63^{\prime \prime}$ \\
\hline $\begin{array}{l}\text { FTC-6 } \\
\text { FTC-7 }\end{array}$ & Bkalti & & & \\
\hline $\begin{array}{l}\text { FTC-7 } \\
\text { FTC-8 }\end{array}$ & $\begin{array}{l}\text { Baklouti } \\
\text { Sisseb }\end{array}$ & Chébika, kairouan & N35 '66’39” & E9 $93^{\prime} 16^{\prime \prime}$ \\
\hline FTC-9 & Sisseb & & & \\
\hline FTC-10 & Baklouti & Sbikha, Kairouan & N35 '96'02" & E10 02'22" \\
\hline FTC-11 & Chaabani & & & \\
\hline
\end{tabular}

*FTC: Faculty of Science (Tunis) Capsicum annuum.

annuum $\mathrm{L} ; 2 \mathrm{n}=2 \mathrm{x}=24$ ) widely cultivated in open field from April to September are important vegetable species in Tunisia with 280 thousands tones of production on 18.5 thousands ha area (FAO, 2010). Accessions of pepper were probably developed by spontaneous crossing and selection of accessions over a period of years. Collection and maintenance of the genetic diversity are important to avoid the genetic erosion. The characterization and the evaluation of accessions maintained in gene banks are of fundamental importance. For this purpose, multivariate methods have become an important tool in the assessment of maintained genotypes (Sudré et al., 2010).

Phenotypic variability can be quantified by multivariate analysis such as canonical analysis and Mahalanobis distance $D^{2}$. These estimates seem to be a powerful tool in the assessment of genetic diversity in others species such as rice, cowpea, tomato (Misra et al., 2004; Narayanankutty et al., 2005; Peter and Rai, 1976) and also chilli (Sundaram et al., 1980; Mehra and Peter, 1980; Varalakshmi and Harribabu, 1991; Roy and Sharma, 1996; Sreelathakumary and Rajamony, 2004) based on multiple characters. These techniques were performed to classify genotypes in groups and facilitate the choice of parents for hybridization.

Such information is lacking for Capsicum in Tunisia. Thus, we undertake this study which would provide some useful supplemental information to genetic divergence available in this germplasm. The first objective of this investigation was to assess the proximity of 11 landraces tested from different regions with each other on the basis of phenotypic characteristics. The second objective was to identify highly divergent clusters and promising breeding accessions for high yield and fruit better characteristics.

\section{MATERIALS AND METHODS}

Eleven pepper landraces (C. annuum) were sown and assessed at the Faculty of Sciences of Tunis. Accessions were collected from several regions of north and the centre of Tunisia (Bizerte, Cap Bon, kairouan and Sousse) characterised by different environmental conditions (Table 1). Coordination was established with the Regional Commissioner for Agricultural Development (CRDA) for visits to various farming locations for collecting material. Seven morphologic characters: Plant height, fruit length, fruit diameter fruit wall thickness, placenta weight, number of fruits per plant and fruit yield per plant were assessed (Table 1). Seeds were sown in plastic bags containing 3:1 peat and sand mixture in the late of January. Plants eight-weeks-old was transplanted in the field. The soil was sandy loam type. Seedlings were transplanted at a spacing of $60 \times 30 \mathrm{~cm}$ in individual plots of $3 \times 1.2 \mathrm{~m}$ size. The experiments were planted in a randomized complete block design (RCBD) with three replications. The rows lengths were $0.5 \mathrm{~m}$ apart. Plants were irrigated every 3 to 4 days according to substrate humidity, with all recommended agronomic practices. All landraces were harvested in late August. 50 seeds for each accession were sown by replication and 15 plants were assessed. Data collected were subjected to $D^{2}$ Mahalanobis distance and canonical analysis for genetic divergence (Mahalanobis 1936; Rao 1952).

\section{RESULTS}

Results derived from ANOVA exhibited a wide range of variation in the assessed characters, indicating high degrees of agronomical variation among accessions tested. Results are presented in Table 2. It is revealed from the observations that accession FTC-3 (mean 86.1 $\mathrm{cm}$ ) was the tallest, whereas accession FTC-11 was the smallest $(61 \mathrm{~cm})$ of all, the other accessions having moderate plant height type. In term of economic fruit characters, FTC-6 recorded the highest fruit diameter $((5.2 \mathrm{~cm})$, fruit wall thickness $(3.3 \mathrm{~mm})$ and the least fruit length $(3.3 \mathrm{~cm})$. However, FTC-2 recorded maximum fruit length and the highest placenta weight, number of fruit per plant and fruit yield per plant. FTC-11 showed lowest values for all agronomic and economic characters.

Based on Malahanobis generalized distances $\left(D^{2}\right)$, germplasm studied was divided into three clusters (Table 3). Cluster I included 9 genotypes (FTC-1, FTC-2, FTC-3, FTC-4, FTC-5, FTC-7, FTC-9, FTC-8 and FTC-10), while 
Table 2. Mean ( \pm standard errors) and coefficient of variation (CV\%) of seven morphologic characters assessed in 11 accessions of Capsicium annuum L.

\begin{tabular}{lccccccc}
\hline Accessions & $\begin{array}{c}\text { Plant height } \\
(\mathbf{c m})\end{array}$ & $\begin{array}{c}\text { Fruit length } \\
(\mathbf{c m})\end{array}$ & $\begin{array}{c}\text { Fruit diameter } \\
(\mathbf{c m})\end{array}$ & $\begin{array}{c}\text { Fruit wall } \\
\text { thickness } \\
(\mathbf{m m})\end{array}$ & $\begin{array}{c}\text { Placenta } \\
\text { weight }(\mathbf{g})\end{array}$ & $\begin{array}{c}\text { Number of } \\
\text { fruits per plant }\end{array}$ & $\begin{array}{c}\text { Fruit yield per } \\
\text { plant(g) }\end{array}$ \\
\hline FTC-1 & $66.9 \pm 10.6^{\mathrm{bcd}}$ & $12.5 \pm 2.4^{\mathrm{b}}$ & $2.2 \pm 0.5^{\mathrm{e}}$ & $2.5 \pm 0.4^{\mathrm{bc}}$ & $2.7 \pm 1^{\mathrm{cd}}$ & $46.2 \pm 14.9^{\mathrm{b}}$ & $1151 \pm 137.2^{\mathrm{bc}}$ \\
FTC-2 & $77.7 \pm 12.5^{\mathrm{ab}}$ & $15.2 \pm 2.6^{\mathrm{a}}$ & $3 \pm 0.4^{\mathrm{b}}$ & $2.9 \pm 0.5^{\mathrm{b}}$ & $4.9 \pm 1.8^{\mathrm{a}}$ & $76.2 \pm 23.9^{\mathrm{a}}$ & $3282 \pm 127.6^{\mathrm{a}}$ \\
FTC-3 & $86.1 \pm 13.7^{\mathrm{a}}$ & $12.2 \pm 2^{\mathrm{b}}$ & $1.8 \pm 0.3^{\mathrm{e}}$ & $2.3 \pm 0.6^{\mathrm{c}}$ & $3.8 \pm 1.3^{\mathrm{bc}}$ & $44 \pm 6.6^{\mathrm{bc}}$ & $1027 \pm 104.1^{\mathrm{bcd}}$ \\
FTC-4 & $81.8 \pm 14.1^{\mathrm{ab}}$ & $14.8 \pm 3^{\mathrm{a}}$ & $2.7 \pm 0.7^{\mathrm{bcd}}$ & $2.3 \pm 0.3^{\mathrm{bc}}$ & $3.2 \pm 0.9^{\mathrm{d}}$ & $39.7 \pm 9^{\mathrm{bc}}$ & $825 \pm 183.9^{\mathrm{bcd}}$ \\
FTC-5 & $77 \pm 12.5^{\mathrm{abc}}$ & $10.1 \pm 1.7^{\mathrm{c}}$ & $2.8 \pm 0.6^{\mathrm{bc}}$ & $2.6 \pm 0.4^{\mathrm{bc}}$ & $4.5 \pm 1.5^{\mathrm{ab}}$ & $47.3 \pm 18^{\mathrm{b}}$ & $1397 \pm 120^{\mathrm{b}}$ \\
FTC-6 & $77 \pm 16.7^{\mathrm{ab}}$ & $3.3 \pm 0.4^{\dagger}$ & $5.2 \pm 0.4^{\mathrm{a}}$ & $3.3 \pm 0.6^{\mathrm{a}}$ & $4.5 \pm 1.5^{\mathrm{ab}}$ & $46.4 \pm 12.9^{\mathrm{b}}$ & $1208 \pm 118.3^{\mathrm{bc}}$ \\
FTC-7 & $78.8 \pm 12.5^{\mathrm{ab}}$ & $7.2 \pm 2.3^{\mathrm{de}}$ & $2.7 \pm 0.3^{\mathrm{bcd}}$ & $2.6 \pm 0.4^{\mathrm{bc}}$ & $3.7 \pm 1^{\mathrm{bc}}$ & $36.5 \pm 7^{\mathrm{bcd}}$ & $614 \pm 124.1^{\mathrm{bcd}}$ \\
FTC-8 & $80.6 \pm 14.30^{\mathrm{ab}}$ & $8.4 \pm 1.9^{\mathrm{cde}}$ & $2.7 \pm 0.3^{\mathrm{bcd}}$ & $2.3 \pm 0.4^{\mathrm{c}}$ & $3.4 \pm 1^{\mathrm{bcd}}$ & $36.5 \pm 7.7^{\mathrm{bcd}}$ & $639 \pm 162.5^{\mathrm{bcd}}$ \\
FTC-9 & $67.5 \pm 13.4^{\mathrm{bcd}}$ & $7.2 \pm 1.8^{\mathrm{de}}$ & $2.4 \pm 0.3^{\text {cde }}$ & $2.4 \pm 0.4^{\mathrm{bc}}$ & $2.7 \pm 1^{\mathrm{cd}}$ & $34.7 \pm 5.5^{\mathrm{de}}$ & $363 \pm 162.6^{\mathrm{cd}}$ \\
FTC-10 & $74.5 \pm 14^{\mathrm{abc}}$ & $9.1 \pm 2.2^{\text {cd }}$ & $2.8 \pm 0.7^{\mathrm{bcd}}$ & $2.2 \pm 0.5^{\mathrm{c}}$ & $2.5 \pm 1^{\mathrm{d}}$ & $31.7 \pm 13.4^{\mathrm{cd}}$ & $654 \pm 108.2^{\mathrm{bcd}}$ \\
FTC-11 & $61 \pm 7.9^{\mathrm{cd}}$ & $6.3 \pm 0.65^{\mathrm{e}}$ & $2.4 \pm 0.2^{\text {cde }}$ & $2.4 \pm 0.3^{\mathrm{bc}}$ & $1.1 \pm 0.9^{\mathrm{e}}$ & $19 \pm 9^{\mathrm{e}}$ & $207 \pm 83^{\mathrm{d}}$ \\
CV & 0.23 & 0.45 & 0.35 & 0.25 & 0.50 & 0.52 & 1.21 \\
\hline
\end{tabular}

Means followed by the different letter within each column significantly different based in Duncan's test $(P<0.05)$.

Table 3. Intra-(bold) and intercluster divergence (D2 values) among three clusters of $C$. annuum.

\begin{tabular}{ccccc}
\hline Clusters & I & II & III & Accessions included in clusters \\
\hline I & 225.1 & 5283.6 & 1112.2 & FTC-1 ;FTC-2 ; FTC-3; FTC-4 ; FTC-5 ; FTC-7 ; FTC-8; FTC-9; FTC-10 \\
II & & 937.8 & 4171.4 & FTC6 \\
III & & & 462.2 & FTC-11 \\
\hline
\end{tabular}

Table 4. Mean ( \pm standard errors) of seven morphologic characters assessed in three different clusters.

\begin{tabular}{lccc}
\hline Parameter & Cluster I & Cluster II & Cluster III \\
\hline Plant height $(\mathrm{cm})$ & $77 \pm 12.5^{\mathrm{b}}$ & $79 \pm 16.7^{\mathrm{a}}$ & $61 \pm 7.9^{\mathrm{b}}$ \\
Fruit length (cm) & $10.75 \pm 1.9^{\mathrm{a}}$ & $3.3 \pm 0.4^{\mathrm{c}}$ & $6.3 \pm 0.65^{\mathrm{b}}$ \\
Fruit diameter (cm) & $2.6 \pm 0.4^{\mathrm{b}}$ & $5.2 \pm 0.4^{\mathrm{a}}$ & $2.4 \pm 0.2^{\mathrm{c}}$ \\
Fruit wall thickness (mm) & $2.5 \pm 0.5^{\mathrm{b}}$ & $3.3 \pm 0.6^{\mathrm{a}}$ & $2.4 \pm 0.3^{\mathrm{b}}$ \\
Placenta weight (g) & $3.5 \pm 1.3^{\mathrm{b}}$ & $4.5 \pm 1.5^{\mathrm{a}}$ & $1.1 \pm 0.9^{\mathrm{c}}$ \\
Nofruits/plant & $42.45 \pm 12.4 \mathrm{~b}$ & $46.4 \pm 12.9^{\mathrm{a}}$ & $19 \pm 9^{\mathrm{c}}$ \\
Yield/plant (g) & $1106.12 \pm 137^{\mathrm{a}}$ & $1208.5 \pm 118.3^{\mathrm{a}}$ & $207.7 \pm 83^{\mathrm{b}}$ \\
\hline
\end{tabular}

Means followed by the different letter within each column significantly different based in Duncan's test $(P<0.05)$.

Cluster II (FTC-6) and Cluster I (FTC-11) consisted of solitary individual genotype. All pairwise distances between cluster groups were significant $(P<0.0001)$. Each cluster group displays small within-cluster genetic variation relative to the between-cluster genetic variation. The average intracluster divergence was ranged from 225.1 to 937.8. Intracluster divergence was highest for cluster II (D2=937.77). Whereas, the intercluster divergence ranged from 1112.2 to 5283.6. Cluster I and III $\left(D^{2}=1112.2\right)$ recorded the lowest intercluster divergence whilst cluster I and cluster II $\left(D^{2}=5283.6\right)$ registered maximum intercluster value.
Cluster I had highest mean for fruit length values and moderate behavior type for all others characters (Table 4). Whereas cluster II was promising for the economic fruit characters namely fruit diameter, fruit wall thickness, placenta weight, number of fruits per plant and fruit yield per plant. While cluster III consisted of one accession and showed lowest values for all fruit traits. The phenotypic divergence was shown through canonical analysis pattern in terms of spatial distribution. Canonical Discriminant Analysis was performed using all variables and the distribution of each individual against Axis 1 and Axis 2 is presented in Figure 1. The first three canonical 


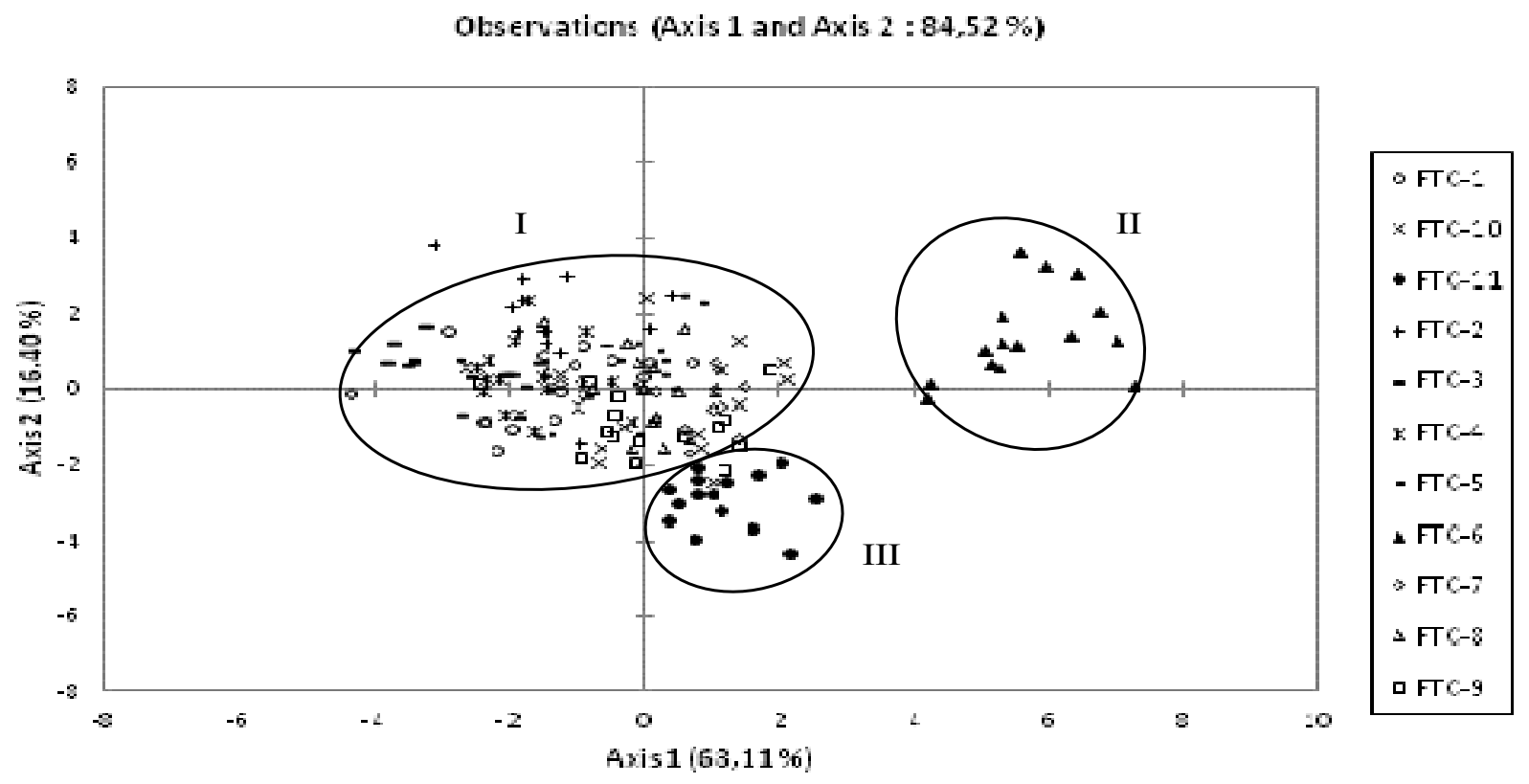

Figure 1. Spatial distribution of 11 genetic accessions of $C$. annuum against the first two canonic variates (Axis 1-Axis 2).

Table 5. Eigen values, Eigenvectors, proportion of variation and communality variation estimated for the first three principal components in the 11 landraces of $C$. annuum landraces.

\begin{tabular}{lcc}
\hline Parameter & Axis 1 & Axis 2 \\
\hline Plant height & -0.071 & 0.431 \\
Fruit length & -0.753 & 0.485 \\
Fruit diameter & 0.797 & 0.522 \\
Fruit wall thickness & 0.363 & 0.381 \\
Placenta weight & 0.062 & 0.762 \\
Number of fruits/plant & -0.129 & 0.839 \\
Yield/plant & -0.113 & 0.708 \\
Eigenvalue & 4.539 & 1.094 \\
Proportion of variation (\%) & 68.115 & 16.409 \\
Cumulative variance (\%) & 68.115 & 84.524 \\
\hline
\end{tabular}

variates explained $92.21 \%$ of total variability amongst the 11 landraces under study (Table 5$)$. Axis $1(68.11 \%$ of variability) had fruit diameter as the trait with the highest and positive coefficient (0.797) and fruit length as the traitwith the highest, negative coefficient $(-0.753)$. The second variate was highly correlated with number of fruits per plant, placenta weight and fruit yield per plant $(\mathrm{r}=$ $0.839, \quad 0.762$ and 0.708 , respectively). The genetic accessions in clusters II (FTC-6) and III (FTC-11) were distinctly delineated in the Axis1-Axis2 chart. The genetic accessions (FTC-1, FTC-2, FTC-3, FTC-4, FTC-5, FTC7, FTC-9, FTC-8 and FTC-10), all belonging to cluster I, were closer to cluster III (FTC-11). FTC-6 was very distinct from all material studied.

\section{DISCUSSION}

Considerable degree of divergence was observed at intergenetic stock (between genotypes), also at intercluster (between clusters), and at intracluster (within cluster) levels of variability in $C$. annuum landraces. At intercluster or intergenotype level, the characteristics that played the greatest role in differentiation between genotypes and clusters were the number of fruits per plant, fruit diameter, placenta weight, and fruit length. On the basis of characters correlation with canonical variates, number of fruits per plant was the highest contributor toward the phenotypic diversity followed by fruit diameter. The least contributing characteristic 
towards divergence was plant height (Table 5). Number of fruits per plant was also the major character generating groups in Indian accessions of $C$. annuum (Mehra and Peters, 1991). In the study of Thul et al. (2009) on Capsicum species, fruit diameter and number of fruits per plant was also the most important contributor toward phenotypic diversity.

Based on relative magnitude of $D^{2}$ values, accessions studied were grouped into three clusters. Minimum intracluster distance (cluster I) indicated much more homogeneity in genetic constitution of genotypes in that cluster. While maximum intracluster distance (cluster II) expressed high genetic heterogeneity among genotypes included. As well as the highest value of intercluster distance (cluster I and II) indicated also more heterogeneous genetic constitution of genotypes included in both clusters. In contrast, minimum intercluster distance (cluster I and III) indicated closer relationship among the genotypes included (Varalakshmi and Harribabu 1991; Roy and Sharma, 1996).

No association of clusters with the collection site was observed. This result is in agreement with the finding of (Zewdie and Zeven, 1997; Sreelathakumary and Rajamony, 2004) that the cluster pattern is not always related to geographical distribution. Diversity detected within accessions could mainly be attributed to diverse agro-climatic conditions in Tunisia. Accessions from different regions were sometimes closely related and accessions from the same region had different genetic background. The intraregional diversity could be as a valuable source as interregional diversity for pepper improvement (Lahbib et al., 2012).

Both the conglomeration technique based on Mahalanobis generalized distance and the analysis of the canonic variates was used for the quantification of the genetic divergence among parents. In this study, characters studied differentiated accessions into three different groups from which superior hybrids can be derived. Crosses within the same group should be avoided. In this study, crosses that would be made based on the genetic divergence and on the key agronomic traits involved both clusters; cluster I and cluster II to produce wide variability and transgressive segregants with high heterotic effects. The promising parent accessions that should be considered as reservoir of genes were FTC2, FTC3, FTC-4 and FTC-6.

\section{REFERENCES}

Andrews J (1995). Peppers: The Domesticated Capsicums, new ed. University of Texas Press, Austin.

Andrews J (1998). The Pepper Lady's Pocket Pepper Primer. University of Texas Press, Austin.

Andrews J (1999). The Pepper Trail: History and Recipes from Around the World. University of North Texas Press, Denton, Texas.

Bosland PW, Votava EJ (2000). Peppers: Vegetable and Spice Capsicums. Crop Production Science in Horticulture. CAB International Publishing, Wallingford, England, UK. P. 204.
Bosland PW (1994). Chiles: History, cultivation, and uses. In G. Charalambous, ed., Spices, Herbs and Edible Fungi. Developments in Food Science. pp. 347-366.

Cichewicz RH, Thorpe PA (1996). The antimicrobial properties of chile peppers (Capsicum species) and their uses in Mayan medicine. $J$ Ethnopharmacol. 52:61-70.

Cordell GA, Araujo OE (1993). Capsaicin: Identification, nomenclature, and pharmacotherapy. Ann Pharmacother. 27:330-336

DeWitt D, Bosland PW (1996). Peppers of the World: An Identification Guide. Ten Speed Press, Berkeley, California.

FAO (2010):http://faostat.fao.org/site/567/DesktopDefault.aspx?Pagel $\mathrm{D}=567$ \#ancor.

Krishna De A (2003). Capsicum: The Genus Capsicum. Medicinal and Aromatic Plants - Industrial Profiles. Taylor \& Francis, London and New York.

Lahbib K, Bnejdi F, El Gazzah M (2012). Genetic diversity evaluation of pepper (Capsicum annuum L.) in Tunisia based on morphologic characters. Afr. J. Agric. Res. 23:3413-3417.

Mahalanobis PC (1936). On the generalized distance in statistics. Proc Natl. Acad. Sci. 2:49-55.

Mehra CS, Peters KV (1991). Comparative efficiency of straight selection over selection through discriminant function in chilli. Plant Breeding Abstracts.

Mehra CS, Peter KV (1980). Genetic divergence in chilli. J. Agric. Sci. 50:477-481.

Misra CH, Pandey N, Chaubey GS (2004). Genetic divergence in rain fed semi-deep water rice germplasm. Indian J. Agric. Res. 38:273277.

Narayanankutty C, Sunanda CK, Jaikumaran U (2005). Genetic divergence in pole type vegetable cowpea. Indian J. Hortic. 62:354357.

Palevitch D, Craker LE (1995). Nutritional and medical importance of red pepper (Capsicum spp.). J. Herbs Spices Med. Plants 2:55-83.

Peter KV, Rai B (1976). Genetic divergence in tomato. Indian J. Genet. 36:376-383.

Rao CR (1952). Advanced statistical methods in Biometrics Research. Wiley, New York.

Roy A, Sharma RN (1996). Multivariate analysis in chilli (Capsicum annuum L.). Ann. Agric. Res. 17:130-132.

Sreelathakumary I, Rajamony L (2004). Genetic divergence in chilli (Capsicum annuum L.). Indian J. Hortic. 61:137-139.

Sudré CP, Gonçalves LSA, Rodrigues R, Amaral Júnior ATdo, RivaSouza EM, Bento CdosS (2010). Genetic variability in domesticated Capsicum spp as assessed by morphological and agronomic data in mixed statistical analysis. Genet. Mol. Res. 9:283-294.

Sundaram A, Ramalingam A, Renganathan CR, Sethapathi R (1980). Genetic divergence in chilli. Indian J. Agric. Sci. 50:391-393.

Thul ST, Lal RK, Shasany AK, Darokar MP, Gupta AK, Gupta MM, Verma RK, Khanuja SPS (2009). Estimation of phenotypic divergence in a collection of Capsicum species for yield-related traits. Euphytica 168:189-196.

Varalakshmi B, Harribabu K (1991). Genetic divergence, heritability and genetic advance in chilli (Capsicum annuum L.). Indian J. Genet. 51:174-178.

Zewdie Y, Zeven AC (1997). Variation in Yugoslavian hot pepper (Capsicum annuum L.) accessions. Euphytica 97:81-89. 